\title{
Changes in RNA Transcription during Morphogenesis of Arthrobacter crystallopoietes
}

\author{
By LINDA K. MASSEY*, J. B. CLARK \\ Department of Microbiology \\ AND R. A. JACOBSON \\ Department of Chemistry, Oklahoma University, \\ Norman, Oklahoma, 73069, U.S.A. \\ (Received I I December 1972; revised 26 February 1973)
}

\section{SUMMARY}

Arthrobacter crystallopoietes is a bacterium whose life cycle involves sphere-rodsphere morphogenesis. The molecular mechanism of such cellular differentiation is unknown. It is not clear whether this is regulated by simple metabolic controls such as feedback inhibition or whether expression of the genome is implicated. The present study involves a comparison of RNAs synthesized throughout the life cycle by using competitive RNA-DNA hybridization. The results show that there are differences in the RNAs synthesized at different times. The RNA appears to fall into two general categories, with some sequences always present and other sequences found only at certain times. Morphogenesis thus involves differential transcription of the genome.

\section{INTROIDUCTION}

Arthrobacter crystallopoietes is classified in the family Corynebacteriaceae and the entire genus differs from other members of this family by having a distinct life cycle, which involves sphere-rod morphogenesis (Conn \& Dimmick, 1947; Stevenson, 1961). When stationary phase spherical organisms are transferred to the appropriate medium, the organisms germinate into rods, which elongate, synthesize multiple cross-walls, and finally divide into shorter bacillary organisms, which gradually become spheres. Ensign \& Wolfe (1964) found that in a medium containing glucose and mineral salts $A$. crystallopoietes grow and divide only as spheres; however, the addition of any of a number of compounds induced elongation and growth as rods. When the inducer was depleted the rods once again reverted to spheres. In each case, the bacteria go through the life cycle synchronously.

Several biochemical events are associated with morphogenesis of Arthrobacter crystallopoietes. These include the accumulation of fats during rod growth and their depletion during shortening (Ferdinandus, 1969; Ferdinandus \& Clark, 1969). Lipogenic enzymes reach highest specific activities during rod-formation; while lipolytic and gluconeogenic enzymes have their highest specific activities during fragmentation. It is significant that several of the inducers of morphogenesis are ketogenic compounds (Ensign \& Wolfe, 1964).

Krulwich \& Ensign (1968, 1969) found that enzymes associated with bacterial walls vary in amount during different stages of the life cycle and under different growth conditions. The polysaccharide backbones of the walls of rods are longer and more homogeneous in

* Present address: Department of Microbiology, Health Sciences Center, 801 N.E. 13th, Oklahoma City, Oklahoma, 73ro4, U.S.A. 
length than those of the spheres, while additional glycine is present in the peptide crossbridges of the sphere (Krulwich, Ensign, Tipper \& Strominger, 1964a,b).

While these biochemical changes can be associated with the morphological changes in Arthrobacter crystallopoietes, little is known of control mechanisms functioning during morphogenesis. Ferdinandus (1969) has demonstrated feedback inhibition of several fatty acid enzymes during the life cycle. However, changes in specific activity of enzymes may be due to either metabolic control by feedback inhibition or genetic control through repression and induction of messenger RNA synthesis or both.

Changes in transcription would result in a change in the mRNA species present (Aronson, 1965) and this may be detected by DNA-RNA hybridization, the most sensitive method for comparing RNA sequences (Bautz, 1967; Gillespie, 1968). The results of competition experiments between RNA species synthesized at various stages of morphogenesis to determine the uniqueness of $\mathrm{mRNA}$ from rods and spheres are described.

\section{METHODS}

Organism and growth. Arthrobacter crystallopoietes (ATCC 1548I) was grown at $30{ }^{\circ} \mathrm{C}$ in TGY broth, containing (w/v): tryptone, $0.5 \%$; glucose, $0.1 \%$ and yeast extract, $0.25 \%$, either in Erlenmeyer flasks in a New Brunswick model VS rotary shaker at $175 \mathrm{rev} / \mathrm{min}$ or in a $41 \mathrm{New}$ Brunswick Microferm. Stock cultures were maintained on agar plates containing TGY and transferred at $48 \mathrm{~h}$ intervals. The inoculum for liquid cultures $(\mathrm{I} \%, \mathrm{v} / \mathrm{v})$ was developed from $48 \mathrm{~h}$ agar cultures by growing in broth for $24 \mathrm{~h}$. The initial extinction was 0.04 at $475 \mathrm{~nm}$ measured in a Spectronic 20 (Bausch \& Lomb). Morphogenesis of A. crystallopoietes was followed by microscopic examination of bacteria stained by the method of Webb (1954).

Bacterial lysis. The lysis procedure was modified from the method of J. Clark \& G. Brownell (personal communication). Bacteria were washed with distilled water and then suspended at $\mathrm{I} g$ wet $\mathrm{wt} / 20 \mathrm{ml}$ of buffered saline $(\mathrm{I} \times \mathrm{SSC}$, containing $\mathrm{NaCl}, 0 . \mathrm{I} 5 \mathrm{M}$ and sodium citrate buffer, $0.015 \mathrm{M}, \mathrm{pH} 7.0$; also used at two- and six-fold concentration and designated $2 \times \mathrm{SSC}$ and $6 \times \mathrm{SSC})$. Lysozyme $(100 \mu \mathrm{g} / \mathrm{ml})$ was added and the bacterial suspension incubated at $37^{\circ} \mathrm{C}$ for $\mathrm{i} h$ or until the viscosity of the suspension increased. Sodium lauryl sulphate solution $(25 \%, \mathrm{w} / \mathrm{v})$ was added to a final concentration of $50 \mu \mathrm{g} / \mathrm{ml}$ and incubation continued for 15 to $30 \mathrm{~min}$ and if necessary, the suspension was heated to $60{ }^{\circ} \mathrm{C}$ for 5 to $30 \mathrm{~min}$.

Enzymes. Electrophoretically pure deoxyribonuclease I(EC. 3.1.4.5) and lysozyme (EC. 3.2.I.I7) were purchased from Worthington Biochemicals, Freehold, New Jersey, U.S.A. Pancreatic ribonuclease (EC. 3.7.7. I6) and pronase (a non-specific protease) were purchased from Sigma Chemicals, St Louis, Missouri, U.S.A. Ribonuclease ( $\mathrm{mg} / \mathrm{ml}$ ) was heated to $95{ }^{\circ} \mathrm{C}$ for Io min to destroy deoxyribonuclease activity and stored at $4{ }^{\circ} \mathrm{C}$. The stock solution of pronase $(2 \mathrm{mg} / \mathrm{ml})$ was pre-incubated at $37^{\circ} \mathrm{C}$ for $\mathrm{I} h$ to destroy nuclease activity and stored at $-10^{\circ} \mathrm{C}$.

Purification of RNA. Magnesium chloride was added to $1.0 \mathrm{~mm}$ and the RNA purified by shaking the lysates vigorously with an equal volume of water-saturated phenol for about I min at room temperature. This solution was centrifuged for $10 \mathrm{~min}$ at $10000 \mathrm{~g}$ and the aqueous layer re-extracted with phenol until very little protein precipitate appeared at the phenol-water interface after centrifugation. The RNA was then precipitated with 2 vol. of $95 \%$ ethanol. The RNA was resuspended in I $\times$ SSC, treated with deoxyribonuclease $\left(50 \mu \mathrm{g} / \mathrm{ml}\right.$ for $\mathrm{I} \mathrm{h}$ at $\left.37^{\circ} \mathrm{C}\right)$, extracted again with phenol until no denatured protein was seenat the phenol-water interface, precipitated with ethanol and stored at $-20^{\circ} \mathrm{C}$. 
Three g of Bio-Gel HTP (Bio-Rad Laboratory, Richmond, California, U.S.A.), a hydroxyapatite gel, was washed three times with $40 \mathrm{ml}$ of potassium phosphate buffer $(0.05 \mathrm{M}$, pH 6.8), the fines decanted, and packed in a column ( $9 \mathrm{~mm}$ diam.). Methyl orange was used to determine void volume and uniformity of packing. Samples containing up to $3 \mathrm{mg}$ of RNA in $0.05 \mathrm{M}-\mathrm{KH}_{2} \mathrm{PO}_{4}$ were applied and eluted with a linear gradient of 0.05 to $0.3 \mathrm{M}-\mathrm{KH}_{2} \mathrm{PO}_{4}, \mathrm{pH} 6 \cdot 8$, with a total volume of $140 \mathrm{ml}$. RNA elution was carried out at $4{ }^{\circ} \mathrm{C}$ with an initial column pressure of $80 \mathrm{~g} / \mathrm{cm}^{2}$ and elution profiles followed at $254 \mathrm{~nm}$ using an Isco UA-2 analyser. All fractions $(2.5 \mathrm{ml})$ containing RNA were pooled and precipitated in $70 \%(\mathrm{w} / \mathrm{v})$ ethanol for hybridization studies.

Sucrose gradients. Twenty-five to $80 \mu \mathrm{g}$ of RNA in $0.1 \mathrm{ml}$ I $\times$ SSC was layered on $4.2 \mathrm{ml}$ of a 5 to $20 \%$ sucrose gradient in SSC and centrifuged $2.5 \mathrm{~h}$ at $10{ }^{\circ} \mathrm{C}$ and $65000 \mathrm{rev} . / \mathrm{min}$ $(420000 \mathrm{~g})$ in the SW $65 \mathrm{Ti}$ rotor in a Beckman L2-65 B ultracentrifuge. Gradients were analyzed by displacement with $60 \%, \mathrm{w} / \mathrm{v}$, sucrose solution and read at $254 \mathrm{~nm}$ in an upward flow cell of an Isco UA-2 analyser. Radioisotopes samples of two or three drops were also collected and counted.

DNA-RNA hybridization. DNA was purified from the cell lysate by the procedure of Marmur (I96I) followed by treatment with ribonuclease $(100 \mu \mathrm{g} / \mathrm{ml})$ for $\mathrm{I} h$ before final deproteinization. DNA was denatured and loaded on to filters using the procedures of Gillespie \& Spiegelman (1965) except that the DNA was loaded in $6 \times$ SSC. One or two absorbance units $(260 \mathrm{~nm})$ of native DNA were loaded on each $25 \mathrm{~mm}$ nitrocellulose filter Type B6 (Schleicher \& Schuell). Efficiency of DNA retention was determined by counting tritiated DNA samples. Blank filters were also given the same washing and heating treatment used for the DNA filters.

Preliminary hybridizations were carried out at $65^{\circ} \mathrm{C}$; later hybridizations, including all saturation and competition curves, were at room temperature in $30 \%(\mathrm{v} / \mathrm{v})$ formamide in water as described by Bonner, Kung \& Bekhor (I967). One or two ml volumes were used for all hybridizations. Competition experiments used the stepwise procedure described by Oda \& Joklik (1967), in which unlabelled RNA is hybridized first, and the filters incubated with $20 \mu \mathrm{g}$ ribonuclease $/ \mathrm{ml}$, followed by a second hybridization with labelled RNA.

Nucleic acid concentration was determined spectrophotometrically using extinction coefficients of $2.35 \times 10^{4} \mathrm{~cm}^{2} / \mathrm{g}$ for RNA and $2.5 \times 10^{4} \mathrm{~cm}^{2} / \mathrm{g}$ for DNA at $260 \mathrm{~nm}$.

Radioactivity determinations. RNA was labelled by addition of carrier free [ $\left.{ }^{3 \cdot 2} \mathrm{P}\right]$ inorganic phosphate $(16.3 \mathrm{Ci} / \mathrm{pmol} ; 300 / \mathrm{Ci} / \mathrm{l}$ of growth media) for periods of $2 \mathrm{~h}$. DNA was labelled with $\left[{ }^{3} \mathrm{H}\right]$ thymidine $(6 \cdot 7 \mathrm{Ci} / \mathrm{mmol} ; 30 \mu \mathrm{Ci} / \mathrm{l}$ of growth media). Radioisotopes were purchased from New England Nuclear, Boston, Massachusetts, U.S.A. Samples were counted in $10 \mathrm{ml}$ of dioxan (Matheson, Coleman \& Bell, Norwood, Ohio, U.S.A., containing $100 \mathrm{~g} / \mathrm{l}$ naphthalene (Beckman, Palo Alto, California, U.S.A.) and $8 \mathrm{~g} / \mathrm{l} \mathrm{Omni-}$ fluor (New England Nuclear) in a Packard Model 3375 liquid scintillation counter.

\section{RESULTS}

Growth and lysis of cultures. Under the conditions of growth outlined in Methods, the complete life cycle of Arthrobacter crystallopoietes takes 22 to $24 \mathrm{~h}$. Greatest rod length occurs between 10 and $\mathrm{I} 2 \mathrm{~h}$, followed by fragmentation. Wall stains reveal many bacteria containing three cross-septa, and both total counts and viable counts indicate a fourfold increase in numbers during the shortening process. Thus, fragmentation may be two closely spaced binary divisions. Fragmentation of the rods is complete after $18 \mathrm{~h}$, and the rods shorten into spheres and enter stationary phase. These older organisms secrete a coating which makes them very resistant to any gentle lysis procedure. 


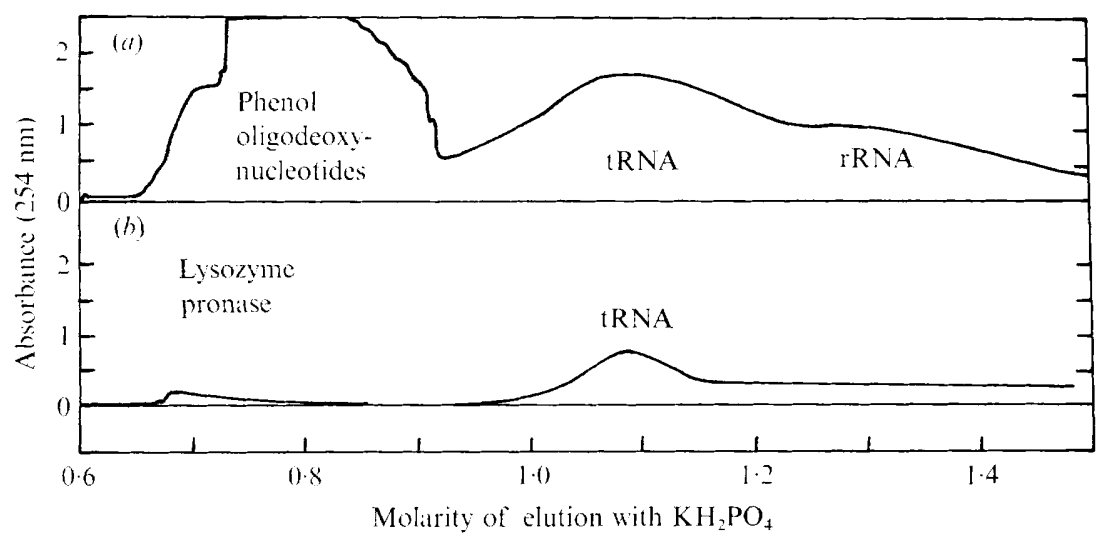

Fig. I. Chromatography of RNA on hydroxyapatite. (a) Arthrobacter RNA purified as in Methods. Nucleic acids were identified on the basis of susceptibility to hydrolysis with $\mathrm{KOH}$. (b) Composite chromatogram showing the position of elution of yeast tRNA ( $\mathrm{mg}$ ), lysozyme (10 $\mathrm{mg}$ ) and pronase (Io mg).

Osmotic shock or treatment with lysozyme alone was not efficient in lysing organisms of any age. Sonication was unsuitable since high mol.wt DNA was needed for hybridization studies. The mixed procedure of lysozyme followed by pronase proved quite efficient. When this failed, addition of sodium lauryl sulphate completed the lysis. Heating was always avoided during DNA purification. Generally speaking, heating was never required for lysis, unless the bacteria had grown for more than $24 \mathrm{~h}$. Rods were more resistant to lysis by lysozyme than were spheres.

Purification and analysis of RNA. RNA was labelled for $2 \mathrm{~h}$ prior to collection at incubation times of 4,10 and $16 \mathrm{~h}$; which corresponded to the germination, intermediate growth, and fragmentation stages. For comparison, bacteria were labelled over their entire growth period and collected at $\mathrm{I} 6 \mathrm{~h}$.

For reasons which will be discussed subsequently, RNA which had been deproteinized only by phenol extraction and pronase treatment proved insufficiently pure for hybridization studies. Thus, the RNA was further purified by chromatography on hydroxyapatite. A typical result is shown in Fig. I $(a)$. Phenol was identified by its characteristic u.v. spectrum. RNA and DNA were differentiated by base hydrolysis of the RNA. Phosphate molarities of the various fractions were calculated as proportions of the linear gradient after correction for the void volume ( $\mathrm{r} \mathrm{ml}$ ).

The column was calibrated with tRNA prepared from yeast (Holley, 1963) and various possible contaminants, including lysozyme, pronase and oligodeoxynucleotides from digestion of DNA with deoxyribonuclease. The positions of elution are shown in Fig. I $(b)$. In all cases, there is adequate separation of RNA from the contaminants. This permitted the omission of several phenol extractions after the RNase and pronase treatments. The yield of RNA was near $100 \%$ (as measured by recovery of alkali-labile radioactive label) and no significant amount of material absorbing at $254 \mathrm{~nm}$ was eluted by the $0 \cdot 4 \mathrm{M}-\mathrm{KH}_{2} \mathrm{PO}_{4}$ used to wash the column. The hydroxyapatite column patterns shown in Fig. I, agree with those reported by Bernardi $(1969 a, b)$ showing similar molarities of elution of various types of RNA.

RNA from the three stages of growth was analysed by ultracentrifugation. A typical pattern is shown in Fig. 2. As expected, when bacteria are exposed to the isotope throughout 


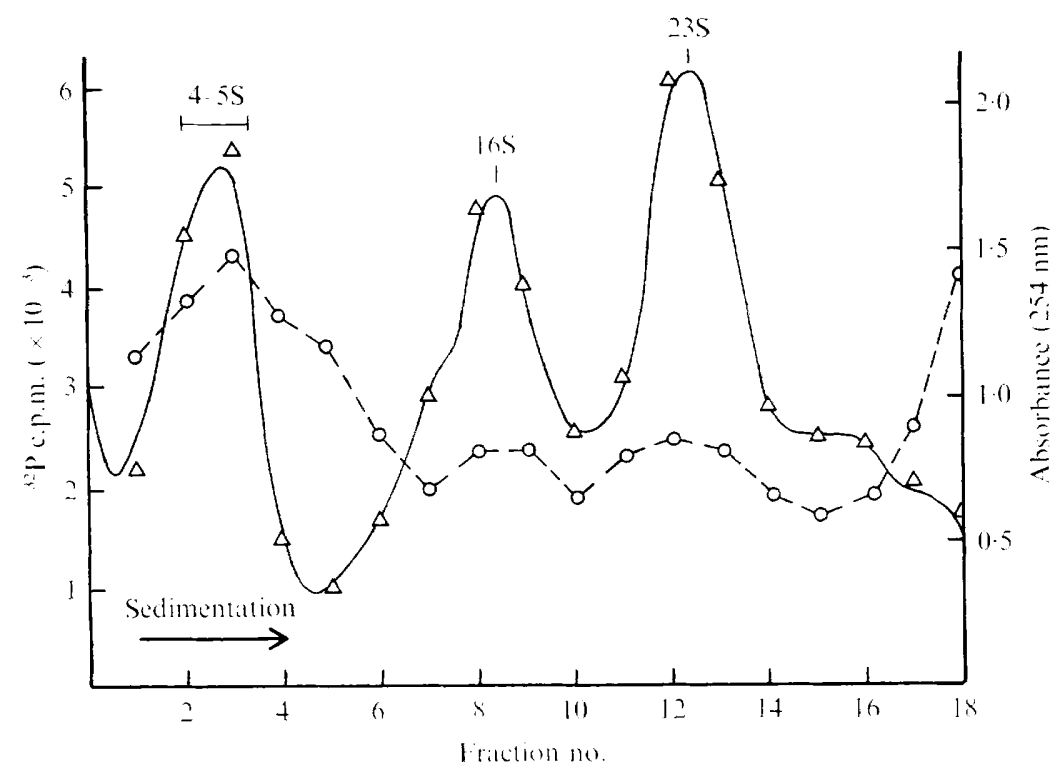

Fig. 2. Sucrose density gradient ultracentrifugation of Arthrobacter RNA. Two types of RNA were analysed, one sample was labelled with [ $\left.{ }^{32} \mathrm{P}\right]$ phosphate over the whole growth cycle $(16 \mathrm{~h})$ and another was labelled for the last $2 \mathrm{~h}$ of growth. The RNA was sedimented through a linear 5 to $20 \%(\mathrm{w} / \mathrm{v})$ sucrose gradient, and analysed by displacement with $60 \%, \mathrm{w} / \mathrm{v}$, sucrose solution through an upward flow cuvette and absorbance read at $254 \mathrm{~nm}(-)$. Fractions ( 3 drops) were collected and the radioactivity counted: $(\Lambda)$, RNA labelled throughout the growth cycle and $\left(\mathrm{O}_{---O}\right)$, pulse-labelled RNA.

the life cycle, virtually all of the label appears in the transfer and ribosomal RNA. The pulse-labelled RNA contains significant differences in the very high mol. wt material and the broad peak between $4 \mathrm{~S}$ and $16 \mathrm{~S}$. Ultracentrifugation of pooled RNA fractions from the HTP column indicated that no degradation of the RNA occurred during the chromotography.

Conditions for hybridization. Preliminary hybridization experiments were run to determine optimum conditions of temperature, time and salt conditions. DNA exhibited best binding to the filters in $6 \times \mathrm{SSC}$ rather than the two times concentration used by Gillespie $\&$ Spiegelman (1965). Better retention of the DNA during hybridization was obtained at room temperature $\left(24^{\circ}\right.$ to $\left.25{ }^{\circ} \mathrm{C}\right)$ in $30 \%, \mathrm{v} / \mathrm{v}$, formamide in water than at $66^{\circ} \mathrm{C}$ without formamide. Efficiency of retention was $92 \%$ in formamide and $80 \%$ at high temperatures. There is also less danger of RNA degradation at room temperature. McConaughy, Laird \& McCarthy (1969) have discussed the validity of formamide technique, as have Gillespie \& Gillespie (I97I). Optimum hybridization of RNA occurred after $12 \mathrm{~h}$ of incubation in $2 \times$ SSC.

Initial hybridization studies indicated very high levels of non-specific binding which were probably due to lysozyme and pronase. Gillespie \& Spiegelman (1965) reported that $20 \mu \mathrm{g}$ of lysozyme/ml or other basic proteins caused non-specific binding of RNA to nitrocellulose filters.

Controls indicated that hydroxyapatite chromatography efficiently removed both enzymes and also DNA oligonucleotides. The additional purification through hydroxyapatite also eliminated the problem of RNA binding to blank filters, with the noise level decreasing from about $3 \%$ of input RNA to 0.1 to $0.3 \%$. 


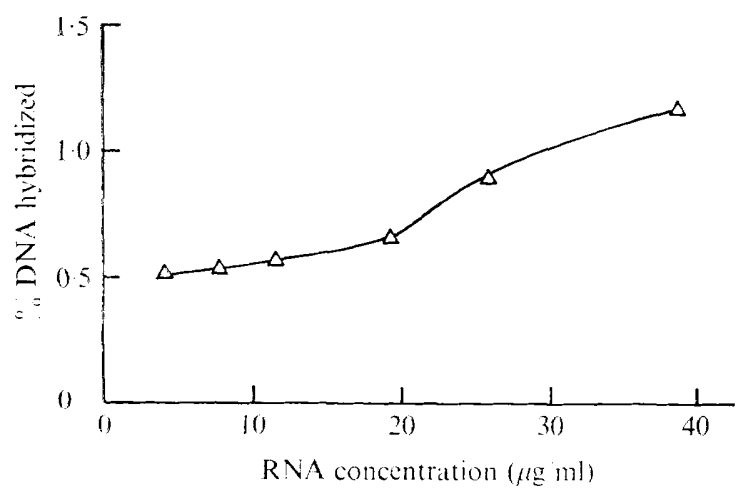

Fig. 3. DNA-RNA hybidization saturation for pulse-labelled RNA form I 6 h culture of Arthrobacter crystallopoietes. DNA on nitrocellulose filters $(74 \mu \mathrm{g} /$ filter $)$ was incubated with varying concentrations of RNA. Two groups of RNA are discernible, since the curve is biphasic. One group is present in high concentrations and saturates at a low amount of input RNA. The other RNA is present in low concentration and has not yet reached a saturation plateau.

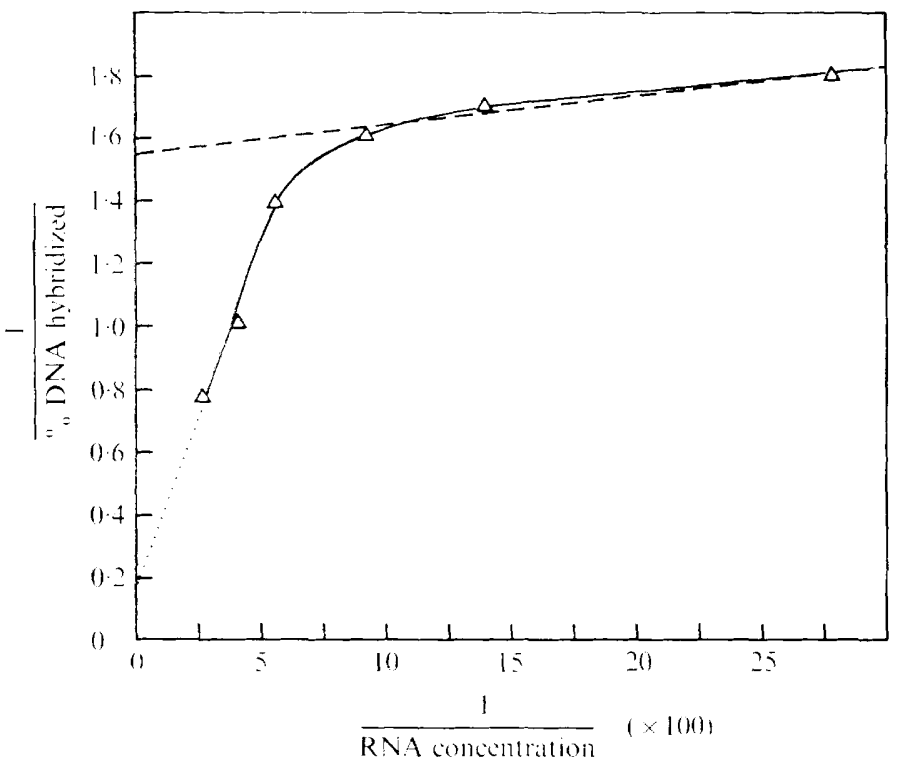

Fig. 4. Double reciprocal plot of the saturation curve shown in Fig. 3. Since the curve in Fig. 3 never reaches a plateau, the saturation values are calculated by plotting the double reciprocal values and extrapolating to zero, an amount which would represent infinite input RNA concentration. $\left(\triangle-\_\right.$), Double reciprocal values for the data in Fig. 3; (---), extrapolation for high concentration RNA component; $(\cdots)$, extrapolation of total RNA.

Hybridization saturation. All saturation curves were biphasic (Fig. 3), indicating the presence of two different classes of RNA (Kennell, I968; Kennell \& Kotoulas, I968). Saturation levels (i.e. the maximum degree of hybridization attainable for a given RNA sample) were calculated from double reciprocal plots, extrapolated to infinite RNA concentration (Fig. 4). The break between the two regions is very clear, making it possible to determine the saturation levels for both the major component and the total mixture. The saturation level of the minor component was then calculated by difference. The results for 


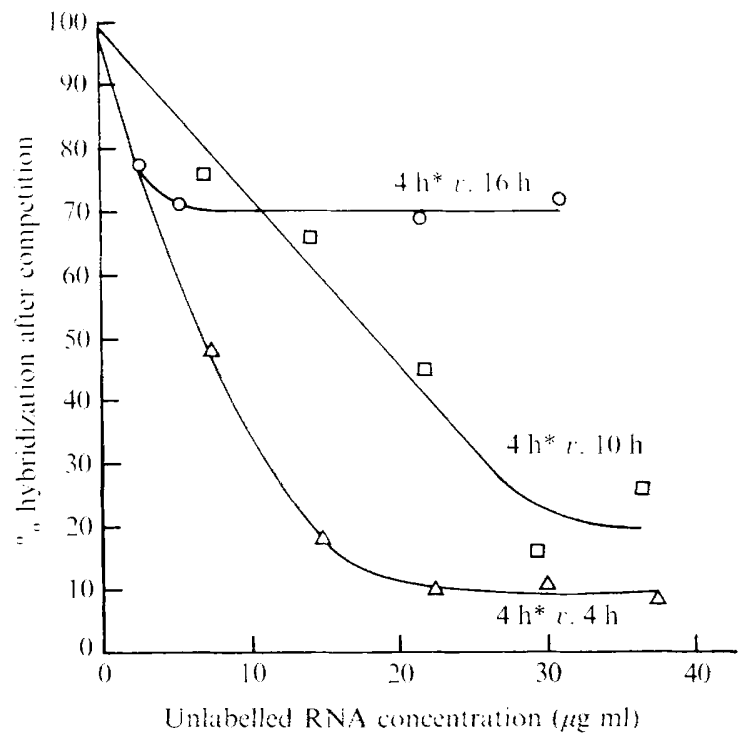

Fig. 5. A typical hybridization competition experiment. Increasing amounts of competing unlabelled RNA from different growth stages $(\Delta, 4 \mathrm{~h} ;[-1,10 \mathrm{~h} ; 0, \mathrm{I} 6 \mathrm{~h})$ were prehybridized to DNA as described in Methods and then hybridized with RNA labelled at $4 \mathrm{~h}$ (designated *) at a concentration of $36.6 \mu \mathrm{g} / \mathrm{ml}$.

\section{Table I. Summary of DNA-RNA saturation hybridization experiments}

The numbers represent the percentage of the DNA sequences which are present in a sample of RNA calculated from double reciprocal plots extrapolated to infinite RNA concentration (Fig. 4). The major component represents RNA sequences present in high concentration and the minor component, those present in low concentration.

\begin{tabular}{lccc} 
& \multicolumn{3}{c}{ Age of culture } \\
& $4 \mathrm{~h}$ & $10 \mathrm{~h}$ & $\mathrm{~J} 6 \mathrm{~h}$ \\
Total fraction of DNA transcribed $(\%)$ & 3.24 & 6.05 & 5.25 \\
Major RNA component $(\%)$ & 1.06 & 1.05 & 0.65 \\
Minor RNA component $(\%)$ & 2.18 & 5.00 & 4.60 \\
tRNA $(\%)$ & - & 0.015 & -
\end{tabular}

Table 2. Summary of competition experiments including a comparison of theoretical values

The results are expressed in terms of percentage of competition provided by prehybridization with the competing RNA. Theoretical competitions (shown in parentheses) are calculated from the data in Table I. For example, if the $3.24 \%$ of the genome transcribed in $4 \mathrm{~h}$ bacteria is part of the $5.25 \%$ transcribed in $16 \mathrm{~h}$ bacteria, the maximum possible competition of unlabelled $4 \mathrm{~h}$ RNA against labelled $\mathrm{I} 6 \mathrm{~h}$ RNA would be $62 \%$. The reverse competition could be as high as $100 \%$.

Competing unlabelled RNA

$\begin{array}{cccc} & & & \\ 4 \mathrm{~h} & \text { (normalized) } & 10 \mathrm{~h} & \mathrm{I} 6 \mathrm{~h} \\ 91 & 100(100) & 80(100) & 30(100) \\ 42 & 46(53) & >99(100) & 60(87) \\ 23 & 25(62) & 66(100) & >99(100)\end{array}$


all three periods in the growth cycle are shown in Table I together with the saturation level for Arthrobacter tRNA, purified through hydroxyapatite. Transfer RNA exhibited a normal, first-order saturation curve.

Hybridization competition. Sequential hybridization conditions were used. Unlabelled RNA was added first to saturate its sites on the DNA. Labelled RNA was added in the second step. The only radioactive RNA which hybridizes represents different sequences.

Controls were run with labelled and unlabelled RNA from the same growth stage and competition assays run for all possible cross-competition systems. The results are summarized in Table 2 and a typical experiment is illustrated in Fig. 5. In the experiments in which unlabelled competing RNA comes from germinating cells $(4 \mathrm{~h})$, only 9I \% competition was observed in the control. In later calculations, this amount was corrected to $100 \%$ and other values involving the same RNA as competitor were adjusted proportionately.

\section{DISCUSSION}

Ribosomal and transfer RNA constitute the bulk of the cellular RNA but represent less than $0.5 \%$ of the genome sequences. On the other hand, mRNA constitutes less than $10 \%$ of the total amount but could contain all the remaining DNA sequences, assuming the entire genome is transcribed. Kennell \& Kotoulas (1968) have discussed the difficulty caused by such mixtures of RNA in hybridization studies and Kennell (1968) has applied their methods successfully to the analysis of Escherichia coli mRNA. A mixture of $50 \%$ labelled mRNA and $50 \%$ labelled tRNA and rRNA can be utilized in hybridization studies. Fig. 2 indicates such a distribution of label during a $2 \mathrm{~h}$ pulse.

Qualitatively the biphasic saturation curve (Fig. 3) agrees with results for Escherichia coli (Kennel, 1968). Furthermore, the data used to plot Fig. 3 can also be used to plot a curve with the same shape as the theoretical curves of Kennel (I968). Kennel demonstrated that the major component RNA species (transfer and ribosomal) would saturate their gene sites at RNA/DNA ratios as low as $1 / 160$, while $m$ RNA required much higher input amounts to approach saturation. For Arthrobacter crystallopoietes, RNAs occurring in large amounts exhibit saturation at RNA/DNA ratios of about I:I. Messenger RNA would require ratios of I00: $\mathrm{I}$ or higher to exhibit saturation plateaus. Unfortunately, such high amounts of mRNA were not available and it is not surprising that this fraction does not plateau in Fig. 3 .

Since plateaux were not attainable, double reciprocal plots were extrapolated to zero to calculate the saturation values (see Fig. 4 and Table I). Straight lines were fitted and intercepts determined by the least squares equation (Teipel \& Koshland, I969; Kennell, I97I).

The saturation level for Arthrobacter crystallopoietes tRNA $0.02 \%$, is close to the value of $0.024 \%$ reported for Escherichia coli (Giacomoni \& Spiegelman, 1962). Presumably, 0.35 to $\mathrm{I} \cdot 5 \%$ of the DNA genome accounts for both the transfer and ribosomal genes as it does in other organisms (Giacomoni \& Spiegelman, I962; Attardi, Huang \& Kabat, 1965; Oishi \& Sueoka, 1965). Table I shows that the major concentration component of the mixed RNA saturated to a level somewhat above this, ranging from $0.65 \%$ to $\mathrm{I} .06 \%$. The extra percentage may indicate mRNA produced constitutively and such mRNAs may well be present in high concentration. Messenger RNA generally contains widely differing amounts of the various RNA sequences (Kennell \& Kotoulas, I969) and Kennell (I968) recognized that the presence of high amounts of certain species of mRNA could affect the level of saturation of tRNA and rRNA. This effect was particularly pronounced in RNA samples labelled for relatively short times, in which the mRNA fraction accounts for $50 \%$ or more of the total label, as it does in our experiments.

Thus, the saturation levels for the major component of Arthrobacter crystallopoietes 
RNA represent only those portions of the genome which are required in large amounts over the entire life cycle. These presumably include tRNA and rRNA and the mRNA sequences present in high amounts.

The competition data (Table 2) can be analysed by making the assumption that there is a total overlap of messages throughout the life cycle. Then, if all of the messages in the $3.24 \%$ of the genome transcribed in $4 \mathrm{~h}$ cultures is included in the $5.25 \%$ transcribed at $\mathrm{I} 6 \mathrm{~h}$, the maximum possible competition would be $62 \%$. Conversely, the RNA from fragmenting bacteria would compete $100 \%$ with the RNA from the germination phase. The actual competition levels, as shown in Table 2, are significantly below these levels. Therefore, there are some unique mRNA sequences in each of these two stages of growth.

A similar comparison can be used to see if the intermediate, Io h cultures contain all of the mRNA from either germinating or fragmenting bacteria. Again $100 \%$ competition is not observed.

Table 2 also lists theoretical competition levels which assume a total overlap of mRNA sequences throughout the life cycle. Comparison with observed data shows an increasing dissimilarity of sequences during the life cycle, with the greatest differences existing between the germination and fragmentation phases. In terms of similarity, only about $\mathrm{I} \cdot \mathrm{O}$ to $\mathrm{I} \cdot 25 \%$ of the genome is expressed in both $4 \mathrm{~h}$ and $16 \mathrm{~h}$ cultures, a figure which represents those omnipresent RNA sequences which are present in high concentrations. Under the conditions used, it was possible to observe competition of omnipresent sequences found in small amounts. However, the qualitative results are clear.

The correlation of RNA changes with the morphogenetic cycle strongly suggests that differential transcription of the genome is involved. However, the cycle occurs while the culture is ageing, and the observed changes which correlate with the morphogenetic life cycle also correlate with the ageing processes of the culture. We doubt whether the degree of changes observed in RNA during morphogenisis would be found in an ageing culture that does nor undergo morphogenesis, but know of no data available for comparison.

This work was supported in part by the Brown Hazen Fund of Research Corporation and the Faculty Research Fund of Oklahoma University. L. K. M was supported by National Institute of Health fellowship no. I-FI-GM-37848 from the National Institute of General Medical Science.

\section{RLFERENCES}

Aronson, A. I. (1965). Characterization of mRNA in sporulating Bacillus cereus, Journal of Molecular Biology ז1 $576-588$.

Attardi, G., Huang, P. C. \& Kabat, S. (1965). Recognition of ribosomal sites in DNA. I. Analysis of the E. coli system. Proceedings of the National Academy of Science 53, 1490-1498.

Bautz, E. K. F. (1967). The product of in vivo and in vitro transcription. In Molecular Genetics, part II, pp. 222-233. Edited by J. H. Taylor. New York: Academic Press.

Bernard, G. (1969a). Chromatography of nucleic acids on hydroxyapatite. I. Chromatography of native DNA. Biochimica et biophysica acta $\mathbf{1 7 4}, 423 \cdots 435$.

Bernardi, G. (1969 b). Chromatography of nucleic acids on hydroxyapatite. III. Chromatography of RNA and polyribonucleotides. Biochimica et biophysica acta $\mathbf{7 7 4}, 449-457$.

Bonner, J., KunG, G. \& Bekhor, I. (1967). A method for the hydridization of nucleic acid molecules at low temperature. Biochemistry 6, 3650-3653.

Conv, H. J. \& Dimmick, I. ( I947). Soil bacteria similar in morphology to Mycobacteria and Corynebacterium. Journal of Bacteriology 54, 29I-303.

ENSIGN, J. C. \& Wolfe, R. S. (1964). Nutritional control of morphogenesis in Arthrobacter crystallopoietes. Journal of Bacteriology 87, 924-932.

Ferdinandus, J. A. (1969). Enzyme control of sphere-rod morphogenesis in Arthrobacter crystallopoietes. Ph.D. Thesis, University of Oklahoma. 
Ferdinandus, J. A. \& Clark, J. B. (1969). Selective inhibition of bacterial enzymes by free fatty acids. Journal of Bacteriology 98, I 109-1113.

Giacomoni, D. \& Spiegelman, S. (1962). Origin and biological individuality of the senetic dictionary. Science, New York 138, 1328-1331.

GillespiE, D. (1968). The formation and detection of DNA-RNA hybrids. In Methods in Enzymology, vol. 3, pp. 64I-668. Edited by L. Grossman and K. Moldave. New York: Academic Press.

Gillespie, S. \& Gillespie, D. (1971). RNA-DNA hybridization in aqueous solutions and in solutions containing formamide. Biochemical Journal I25, $48 \mathrm{I}-488$.

Gillespie, D. \& Spiegleman, S. (J965). A quantitative assay for DNA-RNA hybrids with DNA immobilized on a membrane. Journal of Molecular Biology 12, 829-842.

Holley, R. W. (1963). Large-scale preparation of yeast 'soluble' ribonucleic acid. Biochemistry and Biophysics Research Communication 1o, 186-188.

KenNell, D. (I968). Titration of the gene sites on DNA by DNA-RNA hybridization. II. The Escherichia coli chromosome. Journal of Molecular Biology 34, 85-103.

Kennell, D. (1971). Principles and practices of nucleic acid hybridization. In Progress in Nucleic Acid Research and Molecular Biology, vol. I1, pp. 259-302. Edited by J. N. Davidson and W. E. Cohn. New York: Academic Press.

Kennell, D. \& Kotoulas, A. (1968). Titration of the gene sites on DNA by DNA-RNA hybridization. I. Problems of measurement. Journal of Molecular Biology 34, 71-84.

Krulwich, T. A. \& Ensign, J. C. (1968). Activity of an autolytic N-acetylmuramidase during sphere-rod morphogenesis of Arthrobacter crystallopoietes. Journal of Bacteriology 96, 857-859.

Krulwich, T. A. \& ENSIGN, J. C. (1969). Alteration of glucose metabolism of Arthrobacter crystallopoietes by compounds which induce sphere to rod morphogenesis. Journal of Bacteriology 97, 526-534.

Krulwich, T. A., Ensign, J. C., Tipper, D. J. \& Strominger, J. L. (I964a). Sphere-rod morphogenesis in Arthrobacter crystallopoietes. I. Cell wall composition and polysaccharides of the peptidoglycan. Journal of Bacteriology 94, 734-740.

Krulwich, T. A., Ensign, J. C., Tipper, D. J. \& Strominger, J. L. (1964b). Sphere-rod morphogenesis in Arthrobacter crystallopoietes. II. Peptides of the cell wall peptidoglycan. Journal of Bacteriology $\mathbf{9 4}$, $74 \mathrm{I}-750$.

McConaughy, B. L., Laird, C. D. \& MCCARthy, B. J. (1969). Nucleic acid reassociation in formamide. Biochemistry 8, 3289-3295.

MARMUR, J. (196I). A procedure for the isolation of deoxyribonucleic acid from micro-organisms. Journal of Molecular Biology 3, 208-218.

ODA, K. I. \& JokLIK, W. K. (I967). Hybridization and sedimentation studies on 'early' and 'late' vaccinia messenger RNA. Journal of Molecular Biology 27, 395-418.

Oishi, M. \& Sueoka, N. (1965). Location of genetic loci of rRNA on B. subtilis chromosome. Proceedings of National Academy of Sciences of the United States of America 54, 483-49I.

Stevenson, I. L. (I96I). Growth studies on Arthrobacter globiformis. Canadian Journal of Microbiology 7, $569-575$.

TeIPEL, J. \& Koshland, D. E. (1969). Significance of intermediary plateau regions in enzyme saturation curves. Biochemistry 8, 4656-4663.

WEBB, R. B. (1954). A useful bacterial cell wall stain. Journal of Bacteriology 67, 252-253. 